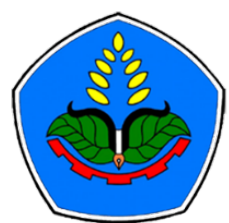

AGROPROSS

National Conference

Proceedings of Agriculture
Proceedings:

Peningkatan Produktivitas Pertanian Era Society 5.0 Pasca Pandemi

Tempat : Politeknik Negeri Jember

Tanggal : 22 Juli 2021

Publisher :

Agropross, National Conference Proceedings of Agriculture

ISBN : 978-623-94036-6-9

DOI : 10.25047/agropross.2021.209

\title{
Karakterisasi Fisiologis 15 Aksesi Sorgum (Sorghum bicolor L. Moench) pada Fase Awal Vegetatif
}

\author{
Author(s): Desty Dwi Sulistyowati ${ }^{(1)^{*}}$, R. M. Yani Abikresna $\mathbf{J}^{(1)}$, Wahyu Widiyono(1), \\ Solichatun ${ }^{(1)}$ \\ (1) Laboratorium Fisiologi Tumbuhan, Pusat Penelitian Biologi-LIPI, Program Studi Biologi, Fakultas \\ MIPA, Universitas Sebelas Maret \\ * Corresponding author:desty_ds@yahoo.com
}

\section{ABSTRACT}

Sorghum (Sorghum bicolor L.) is a cereal crop that has the potential to be cultivated and developed, especially in marginal and dry areas in Indonesia. Knowledge of physiological characterization in the early stages of plant growth is very important, related to the fulfillment of water and nutrients for physiological activities and efficiency of water utilization in sorghum plants. This study aims to determine the growth pattern of 15 sorghum accessions, especially in the vegetative phase of early growth as a basis for knowledge in the growth and subsequent development phases. The research was carried out in the greenhouse of the LIPI Cibinong Biotechnology Research Center with 15 accessions of sorghum planted from January to February 2019. Handling of crops at the Laboratory of Stress Physiology and Seed Conservation of Botany at the LIPI Biology Research Center. Quantitative analysis was conducted based on a Randomized Block Design with 15 sorghum accessions numbers and 3 replications. Data analysis was carried out by presenting a comparison of the average results of data acquisition in the form of tables and histograms, consisting of observations and measurements. From the overall growth data including data on plant height, number of leaves, chlorophyll content, and leaf potential of 15 sorghum accessions for 3 WAP, the overall data obtained can be compared. It can be concluded from some of the measurement data, that the accession that is considered unfavorable is the Kawali accession with the lowest value of all accessions on all measurement parameters. While accessions that can be considered quite good are Buleleng Empok (based on data on plant height and number of leaves), Suri 4 (based on data on plant height, number of leaves and leaf water potential), and Corn Rote (based on data on plant height, number of leaves, and content of leaf water) leaf chlorophyll).
\end{abstract}

\section{Keywords:}

growth phase;

vegetative

phase;

character

physiological;

sorghum.

\section{Kata Kunci: ABSTRAK}

fase

Sorgum (Sorghum bicolor L.) merupakan tanaman serealia yang potensial untuk dibudidayakan dan pertumbuhan; dikembangkan, khususnya pada daerah-daerah marginal dan kering di Indonesia. Pengetahuan tentang karakterisasi fisiologis pada fase awal pertumbuhan pertumbuhan tanaman sangat penting, terkait dengan pemenuhan air dan hara untuk aktivitas fisiologis dan efisiensi pemanfaatan air pada tanaman

fase vegetatif; karakter sorgum. Penelitian ini bertujuan untuk mengetahui pola pertumbuhan 15 aksesi sorgum, khususnya pada fase vegetatif pertumbuhan awal sebagai dasar pengetahuan pada fase pertumuhan dan perkembangan berikutnya. Penelitian dilaksanakan di rumah kaca Pusat Penelitian Bioteknologi LIPI Cibinong dengan 15 aksesi sorgum yang ditanam Januari hingga Februari 2019. Penanganan hasil panen di Laboratorium fisiologis; sorgum Fisiologi Stres dan Konservasi Benih Bidang Botani Pusat Penelitian Biologi LIPI. Analisis kuantitatif, dilakukan berdasarkan Rancangan Acak Kelompok dengan 15 nomor aksesi sorgum dan 3 kali ulangan. Analisis data dilakukan dengan menyajikan perbandingan rata-rata hasil perolehan data ke dalam bentuk tabel dan histogram, terdiri dari pengamatan hasil pengamatan dan pengukuran. Dari keseluruhan data pertumbuhan meliputi data tinggi tanaman, jumlah daun, kadar klorofil,dan potensial daun dari 15 aksesi sorgum selama 3 MST, dapat dibandingkan keseluruhan data yang diperoleh. Dapat disimpulkan dari beberapa data pengukuran, aksesi yang dinilai kurang baik adalah aksesi Kawali dengan nilai yang selalu terendah dari seluruh aksesi pada semua parameter pengukuran. Sedangkan aksesi yang dapat dinilai cukup baik adalah Buleleng Empok (berdasarkan data tinggi tanaman dan jumlah daun), Suri 4 (berdasarkan data tinggi tanaman, jumlah daun dan potensial air daun), dan Jagung Rote (berdasarkan data tinggi tanaman, jumlah daun, dan kadar klorofil daun). 


\section{PENDAHULUAN}

Sorgum (Sorghum bicolor L.) merupakan tanaman serealia yang potensial untuk dibudidayakan dan dikembangkan, khususnya pada daerah-daerah marginal dan kering di Indonesia. Cekaman kekeringan seringkali menjadi pembatas dalam peningkatan produktivitas tanaman pangan. Secara umum cekaman kekeringan dapat mempengaruhi pertumbuhan tanaman, baik dari aspek anatomis, morfologis, fisiologis maupun biokimia (Abdillah et al 2015). Dalam usaha meningkatkan produksi tanaman, kegiatan pemuliaan terus dilakukan seperti dengan melakukan persilangan maupun radiasi. Dalam usaha pemuliaan tersebut diperlukan pengetahuan mengenai potensi dari setiap aksesi yang ada. Hasil pemuliaan tanaman tersebut perlu dievaluasi karakter pola pertumbuhannya. Pengetahuan tentang pola pertumbuhan tanaman sangat penting, terkait dengan pemenuhan kebutuhan air untuk aktifitas fisiologis dan efisiensi pemanfaatan air pada tanaman sorgum. Langkah pemuliaan lebih lanjut dapat ditentukan dari keunggulan masing-masing aksesi (Rifa'i et al, 2015). Penelitian ini bertujuan untuk mengetahui pola pertumbuhan 15 aksesi sorgum, khususnya pada fase pertumbuhan awal. Manfaat penelitian ini selanjutnya untuk untuk diterapkan pada penelitian efisiensi pemanfaatan air oleh tanaman dan efisiensi irigasinya.

\section{METODOLOGI}

Penelitian ini merupakan bagian dari penelitian cekaman kekeringan terhadap aksesi sorgum. Penelitian dilaksanakan di rumah kaca Pusat Penelitian Bioteknologi LIPI Cibinong dengan 15 aksesi sorgum yang ditanam bulan Januari hingga Februari tahun 2019. Analisis kuantitatif, dilakukan berdasarkan Rancangan Acak Kelompok dengan 15 nomor aksesi sorgum dan 3 kali ulangan. Volume penyiraman tanaman per pot sebesar $80 \%$ dari kapasitas lapang, dengan frekuensi dua kali seminggu.
Penanganan hasil panen di Laboratorium Fisiologi Stres dan Konservasi Bidang Botani Pusat Penelitian Biologi LIPI Cibinong. Alat yang digunakan dalam penelitian antara lain lux meter, termohigrometer, soil tester, pot, ember, gelas ukur, alat tulis, penggaris, ajir (bambu), tali, koran, timbangan, neraca analitik, nampan, oven, SPAD (Soil Plant Analysis Development), plastik klip, gelas penutup dan kaca objek, cawan petri, $\mathrm{Li}$-Cor 3000C, Li-Cor 6000 dan label. Bahan yang digunakan dalam penelitian antara lain 15 aksesi benih sorgum, media tanah dan kompos, air, pupuk NPK, pupuk urea, pestisida, fungisida dan aquades.

Tabel 1. Aksesi Sorgum Penelitian

\begin{tabular}{clcl}
\hline No & Aksesi & No & Aksesi \\
\hline 1 & Super 1 & 9 & UPCA \\
2 & Samurai 1 & 10 & Suri 4 \\
3 & WHP 4 & 11 & KS \\
4 & Suri 3 & 12 & Super 2 \\
5 & Kawali & 13 & WR \\
6 & Buleleng Empok & 14 & Samurai 2 \\
7 & 174.66.1.1. & 15 & N6.1.2 \\
8 & Jagung Rote 9 & & \\
\hline
\end{tabular}

Pengukuran pengamatan mingguan selama fase vegetatif dilakukan terhadap beberapa parameter antara lain yaitu tinggi tanaman dan jumlah daun. Pengamatan berikutnya adalah mengenai potensial air daun, dan kadar klorofil yang dilakukan pada umur 3 MST. Analisis data dilakukan dengan menyajikan perbandingan rata-rata hasil perolehan data ke dalam bentuk tabel dan histogram, terdiri dari pengamatan hasil pengamatan dan pengukuran.

\section{HASIL DAN PEMBAHASAN Awal Fase Vegetatif Sorgum}

Pertumbuhan tanaman secara umum dapat dikelompokkan ke dalam tiga tahap. Fase pertama adalah perkecambahan, yaitu saat proses imbibisi air yang ditandai dengan pembengkakan biji sampai dengan sebelum munculnya daun pertama. Fase 
selanjutnya adalah fase pertumbuhan vegetatif, yaitu fase mulai munculnya daun pertama yang terbuka sempurna sampai tasseling dan sebelum keluarnya bunga betina (silking). Pada fase ini dapat diidentifiksi dari jumlah daun yang terbentuk. Fase terakhir adalah fase reproduktif, yaitu fase pertumbuhan setelah silking sampai masak fisiologis (Subekti et al., 2011).

Pertumbuhan awal tanaman sorgum yaitu fase perkecambahan dimulai dengan proses imbibisi air yang ditandai dengan pembengkakan biji sampai dengan sebelum munculnya daun pertama. Terbentuknya sistem perakaran menandakan bahwa tanaman sudah memulai pertumbuhan vegetatifnya, sehingga tanaman mampu memenuhi kebutuhan unsur haranya untuk mendukung pertumbuhan tanaman.
Tanaman yang mulai memasuki fase generatif menandakan berakhirnya pertumbuhan vegetatif tanaman termasuk penambahan tinggi tanaman, jumlah daun, luas daun, dan diameter batang (Anggarini et al., 2013).

\section{Data Pengamatan}

\section{Tinggi Tanaman}

Tinggi tanaman merupakan indikator pertumbuhan maupun sebagai parameter yang digunakan untuk mengukur dan mengetahui pengaruh perlakuan yang diterapkan dalam percobaan atau sebagai indikator untuk mengetahui pengaruh lingkungan. Pertambahan tinggi tanaman merupakan bentuk peningkatan pembelahan sel-sel akibat adanya asimilat yang meningkat (Haryanti, 2014).

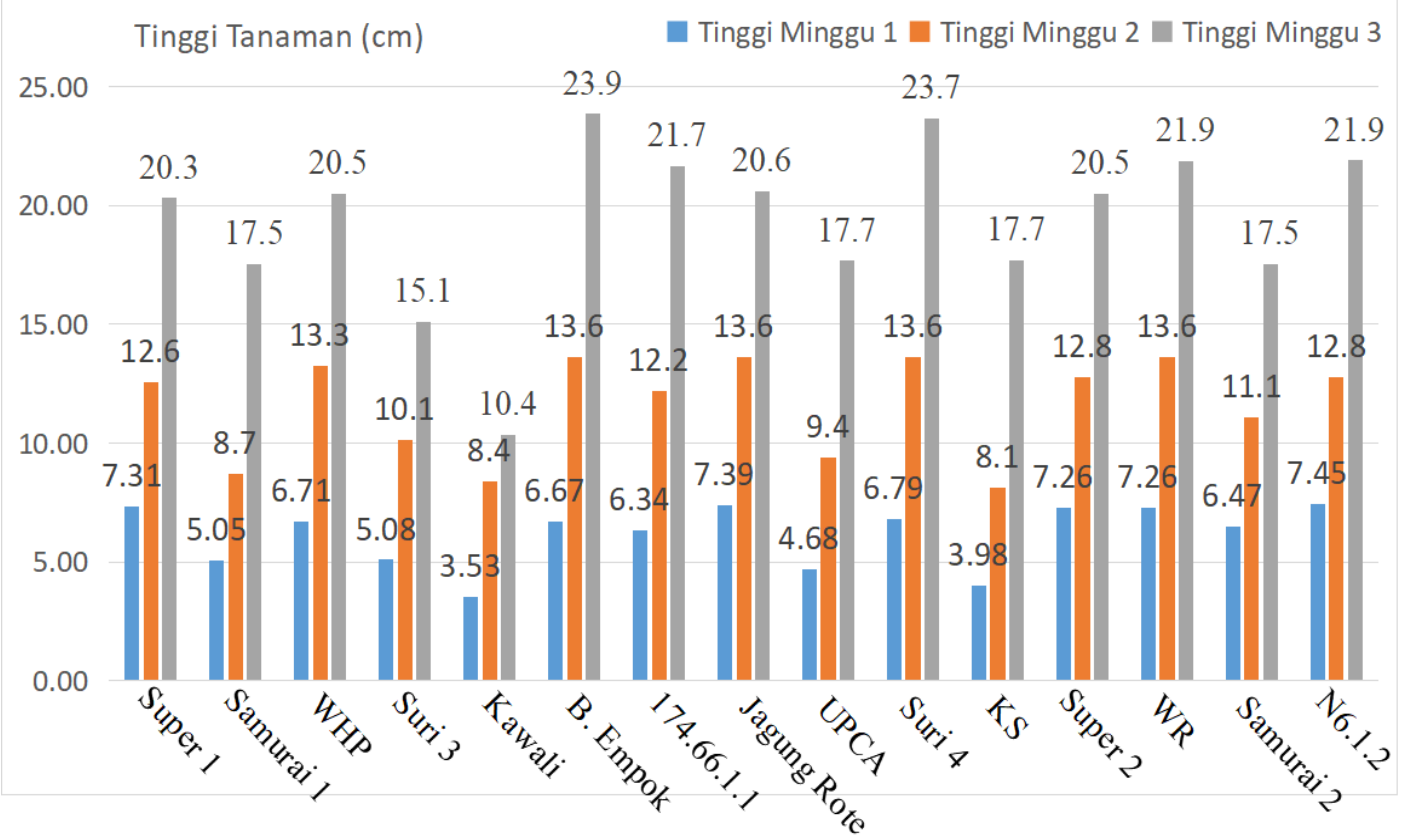

Gambar 1. Diagram pertumbuhan tinggi tanaman sampai umur 3 MST

Data pada Gambar 1 menunjukkan bahwa tinggi tanaman sorgum selalu mengalami peningkatan tiap minggunya. Rata rata tinggi tanaman dari minggu pertama hingga minggu ketiga berturutturut adalah sebesar $6,13 \mathrm{~cm}, 11,6 \mathrm{~cm}$, dan $19,9 \mathrm{~cm}$. Tinggi tanaman terendah pada umur 1 MST adalah pada aksesi Kawali dengan rata-rata tinggi sebesar $3,53 \mathrm{~cm}$, dan tertinggi adalah pada aksesi N6.1.1 dengan rata-rata tinggi sebesar $7,45 \mathrm{~cm}$. Tinggi tanaman terendah pada umur $2 \mathrm{MST}$ adalah pada aksesi KS dengan rata-rata tinggi sebesar $8,1 \mathrm{~cm}$, dan tertinggi pada aksesi Buleleng Empok, Jagung Rote, Suri 4 dan WR dengan rata-rata tinggi sebesar 
13,6 cm. Tinggi tanaman terendah pada umur 3 MST adalah pada aksesi Kawali dengan rata-rata tinggi sebesar $10,8 \mathrm{~cm}$, dan tertinggi pada aksesi Buleleng Empok dengan rata-rata tinggi sebesar $24,6 \mathrm{~cm}$.

\section{Jumlah daun}

Pertumbuhan tinggi tanaman berkaitan dengan pertambahan jumlah daun. Pertumbuhan ini dipengaruhi oleh faktor genetik dan lingkungan sehingga ukuran minimum dan maksimumnya berbeda-beda tergantung jenis tanaman dan lingkungan di sekitarnya (Solikin, 2013). Tanaman sorgum mempunyai biji yang kecil dan pada awal pertumbuhannya sangat lambat dibanding jagung atau kedelai. Pertumbuhan lambat ini terjadi sampai tinggi tanaman mencapai sekitar 20 $\mathrm{cm}$, atau setelah perakarannya mampu mengambil hara lebih banyak dan cepat. Pada varietas berumur sedang $(+90$ hari setelah tumbuh), hal ini terjadi pada 30-35 hari setelah tumbuh, yang merupakan periode kritis karena perkembangan tanaman mulai berubah dari fase vegetatif ke fase pembentukan malai, dan saat itu merupakan akhir pembentukan jumlah daun (Tabri dan Zubachtirodin, 2016).

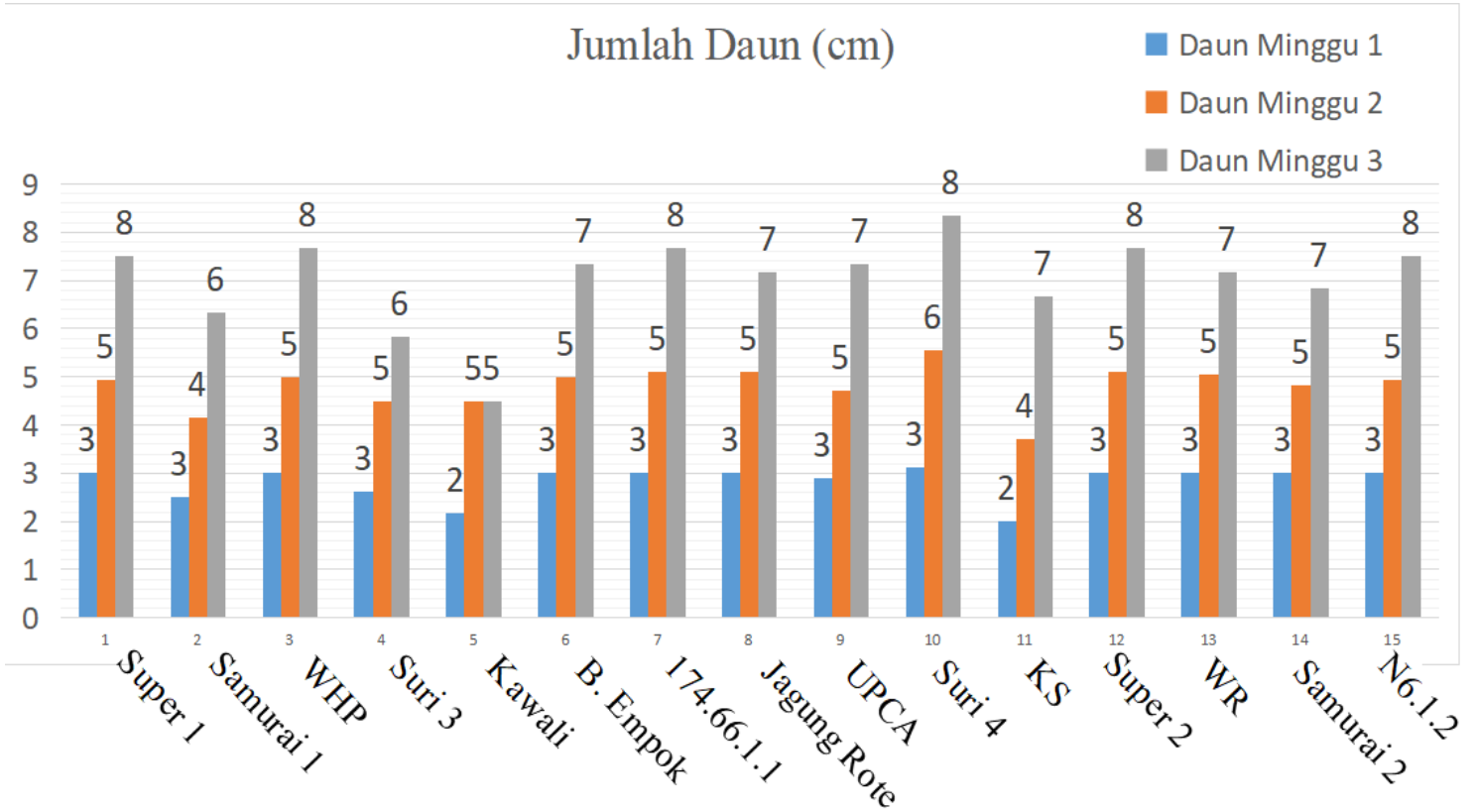

Gambar 2. Diagram perkembangan jumlah daun sampai umur 3 MST

Berkurangnya jumlah dan luas daun pada tanaman yang mengalami cekaman kekeringan disebabkan karena usaha adaptasi tanaman untuk mengurangi kehilangan air melalui proses transpirasi (Hidayati et al., 2017). Data pada Gambar 2 menunjukkan bahwa jumlah daun tanaman sorgum selalu mengalami peningkatan tiap minggunya. Rata rata jumlah daun tanaman dari minggu pertama hingga minggu ketiga berturut-turut adalah sebesar 3, 5, dan 7 helai. Jumlah daun terendah pada umur 1 MST adalah pada aksesi Kawali dan KS, dan aksesi selain itu memiliki jumlah daun yang sama. Jumlah daun terendah pada umur 2 MST adalah pada aksesi Samurai 1 dan KS, dan aksesi selain itu memiliki jumlah daun yang sama. Jumlah daun terendah pada umur 3 MST adalah pada aksesi Kawali, dan selain itu memiliki jumlah daun yang hampir sama yaitu sebanyak $7-8$ helai.

3. Potensial Air Daun

Banyaknya air murni yang dikandung oleh sel atau jaringan 
menentukan potensial air dari suatu sel atau jaringan tumbuhan tersebut. Semakin tinggi kandungan air murni dari suatu jaringan akan semakin tinggi potensial airnya. Oleh karenanya, potensial air sel dan jaringan tumbuhan umumnya bernilai negatif (kurang dari nol). Air akan bergerak dari tempat/jaringan dengan potensial air yang tinggi ke tempat/jaringan dengan potensial air yang rendah. Karena potensial air dari tumbuhan adalah lebih rendah dari pada air di dalam media atau di dalam tanah maka air dapat bergerak dari media tanam ke dalam sel dan jaringan tumbuhan. Potensial air penting artinya untuk mengetahui status air dalam sel atau jaringan tumbuhan, apakah suatu tumbuhan cukup air atau mengalami defisit air (Hamim et al., 1996).

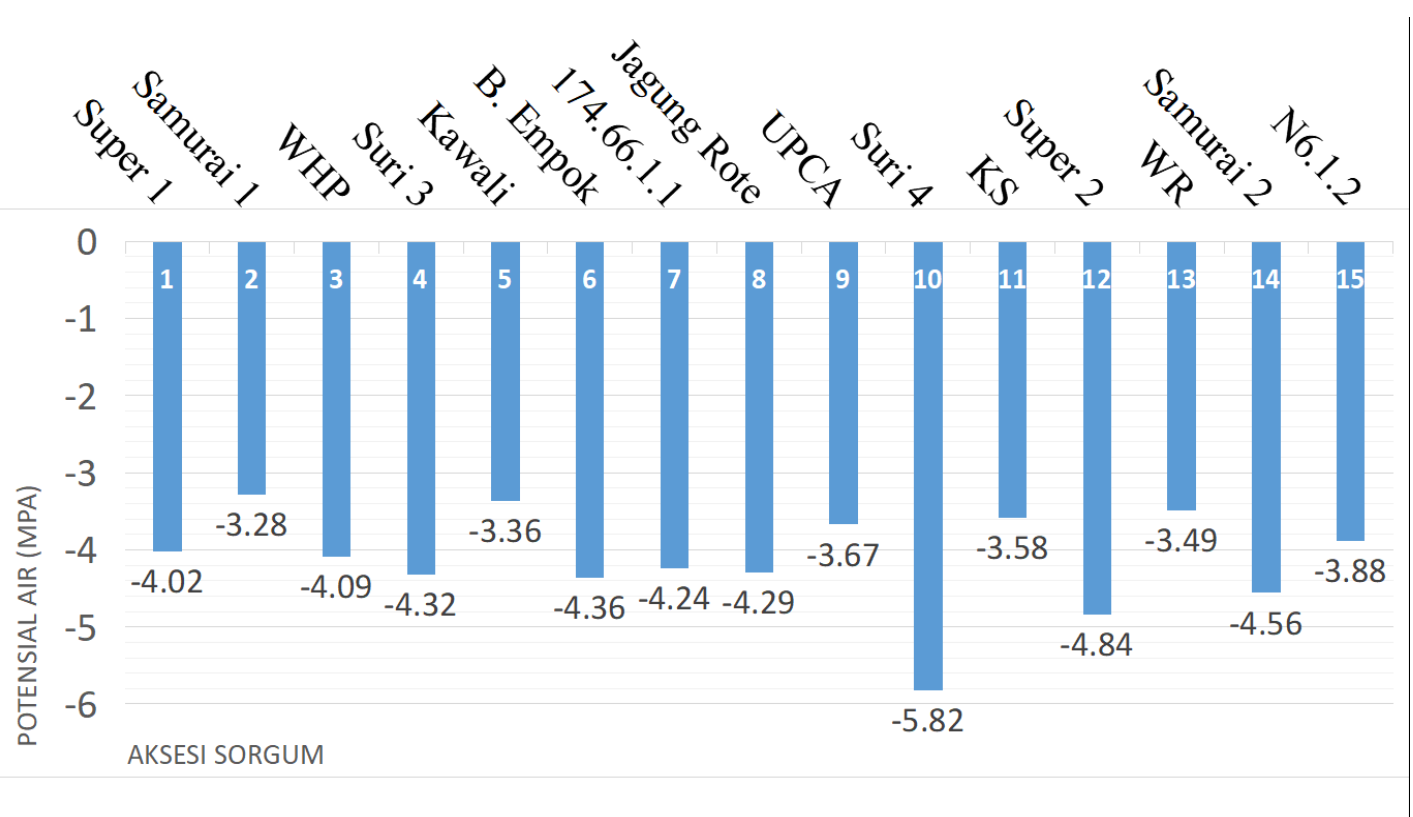

Gambar 3. Diagram pengukuran potensial air daun

Potensial air merupakan salah satu indikator untuk mengetahui ketahanan tanaman terhadap kekeringan. Tanaman yang relatif tahan terhadap kekeringan miliki nilai potensial air kurang negatif (less negative), dan tanaman yang relatif peka terhadap kekeringan memilii nilai potensial air lebih negatif (more negative) (Wahyu Widiyono, komunikasi pribadi). Secara umum nilai potensial daun dari seluruh aksesi sorghum yang diamati, tidak menunjukkan perbedaan yang mencolok. Nilai rata rata potensial air daun sorgum adalah -4,12 MPa. Potensial terendah Suri 4 sebesar -5,82 Mpa (more negative), dan nilai potesial air tertinggi (less negative) terdapat pada aksesi Kawali sebesar -3,36 Gambar 3). Menurut (Naiola, 2000), dalam penelitiannya untuk tanaman berkayu pada lahan gambut, menyebutkan bahwa bila kondisi fisik lingkungan setempat mengalami perubahan drastis akan mempengaruhi kondisi nilai potensial airnya.

\section{Kadar Klorofil}

Klorofil adalah pigmen berwarna hijau yang terdapat dalam kloroplas bersamasama dengan karoten dan xantofil pada semua makhluk hidup yang mampu melakukan fotosintetis. Pada semua tanaman hijau, sebagian besar klorofil berada dalam dua bentuk yaitu klorofil a dan klorofil b (Andi, 2012). Kandungan klorofil daun dapat dipakai sebagai indikator yang terpercaya untuk 
mengevaluasi ketidakseimbangan metabolisme antara fotosintesis dan hasil produksi pada saat kekurangan air. Respons tanaman terhadap kekurangan air pada umumnya ditunjukkan dengan penurunan konsentrasi klorofil daun. Respons fisiologis, seperti konsentrasi klorofil daun, dapat dipakai sebagai salah satu indikator toleransi tanaman terhadap kekurangan air untuk diterapkan dalam seleksi varietas tanaman produksi yang toleran terhadap kekurangan air (Ai dan Banyo, 2011).

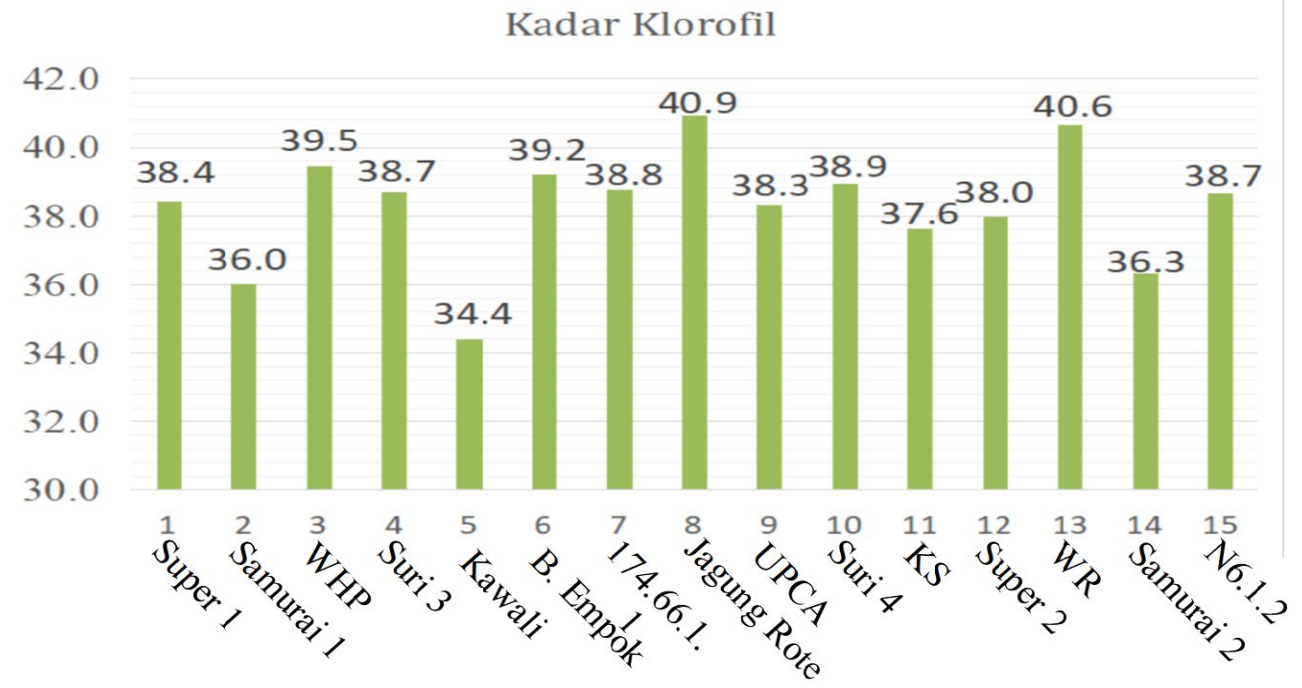

Gambar 4 Diagram pengukuran kadar klorofil (mg/L)

Pengukuran karakter fisiologis seperti kandungan klorofil, merupakan salah satu pendekatan untuk mempelajari pengaruh kekurangan air terhadap pertumbuhan dan hasil produksi, karena parameter ini berkaitan erat dengan laju fotosintesis ( $\mathrm{Li}$ et al., 2006). Kekurangan air dari tingkat paling ringan sampai paling berat mempengaruhi proses-proses biokimia yang berlangsung dalam sel. Kekurangan air mempengaruhi reaksireaksi biokimia fotosintesis, sehingga laju fotosintesis menurun (Ju dan Zhang, 1999). Salah satu aspek fotosintesis yang sangat sensitif terhadap kekurangan air adalah biosintesis klorofil dan pembentukan protoklorofil terhambat pada potensial air sedikit dibawah 0 atm (Salisbury dan Ross, 1992).

Secara umum kadar klorofil daun dari seluruh aksesi pada Gambar 4 tidak terlalu memiliki cukup perbedaan yang sigifikan. Rata rata kadar klorofil daun tanaman dari adalah $38,3 \mathrm{mg} / \mathrm{L}$. Kadar klorofil tertinggi terdapat pada aksesi Jagung Rote sebesar 40,9 mg/L dan terendah pada aksesi Kawali sebesar 34,4 $\mathrm{mg} / \mathrm{L}$.

\section{KESIMPULAN}

Dari keseluruhan data pertumbuhan meliputi data tinggi tanaman, jumlah daun, kadar klorofil, dan potensial daun dari 15 aksesi sorgum selama 3 MST, dapat dibandingkan keseluruhan data yang diperoleh. Dapat disimpulkan dari beberapa data pengukuran, aksesi yang dinilai kurang baik adalah aksesi Kawali dengan nilai yang selalu terendah dari seluruh aksesi pada semua parameter pengukuran. Sedangkan aksesi yang dapat dinilai cukup baik adalah Buleleng Empok (berdasarkan data tinggi tanaman dan jumlah daun), Suri 4 (berdasarkan data tinggi tanaman, jumlah daun, dan potensial air daun), dan Jagung Rote (berdasarkan data tinggi tanaman, jumlah daun, dan kadar klorofil daun). 
DAFTAR PUSTAKA

Abdillah, D., Siswoyo, T. A., Soedradjad, R. (2015). Pengaruh Cekaman Kekeringan Terhadap

Kandungan Fenolik dan Antioksidan Tanaman Sorgum (Sorghum bicolor L. Moench) pada Fase Awal Vegetatif. Berkala Ilmiah Pertanian 1(1): $\quad \mathrm{xx}-\mathrm{xx}$

Ai, N.S., dan Banyo, Y. (2011). Konsentrasi Klorofil Daun Sebagai Indikator Kekurangan Air pada Tanaman. Jurnal Ilmiah Sains 11(2): 166-173

Andi, A. (2012). Hijau Klorofil: Pewarna Alami untuk Pangan. 58-69. SEAFAST Center.

Anggarini, M., Tohari, dan D. Kastono. (2013). Pengaruh Mikoriza Terhadap Pertumbuhan dan Hasil Sorgum Manis (Sorghum bicolor L. Moench) pada Tunggul Pertama dan Kedua. Vegetalika 2(1).

Haryanti R. A., Tohari, dan S. N. H. Utami. (2014). Pengaruh Takaran Pupuk Nitrogen dan Silika terhadap Pertumbuhan Awal (Saccharum officinarum L.) pada Inceptisol. Vegetalika 3(2): $35-44$.

Hamim, D. Sopandie, dan M. Jusuf. (1996). Beberapa Karakteristik Morfologi dan Fisiologi Kedelai Toleran dan Peka Terhadap Cekaman Kekeringan. Bogor.

Hidayati, N., R. L. Hendrati, A. Triani, dan Sudjino. (2017). Pengaruh Kekeringan Terhadap Pertumbuhan dan Perkembangan Tanaman Nyamplung (Callophylum inophyllum L.) dan Johar (Cassia florida Vahl.) dari Provenan yang Berbeda. Jurnal Pemuliaan Tanaman Hutan 11(2): 99-111.
Ju, C. dan J. Zhang. (1999). Effect of Water Stress on Photosystem II Photochemistry and Its Thermostability in Wheat Plants. Journal of Experimental Botany 50(336): 1196-1206.

Li, R., P. Guo, M. Baum, S. Grando, S. Ceccarelli. (2006). Evaluation Of Chlorophyll Content and Fluorescence Parameters As Indicators Of Drought Tolerance In Barley. Agricultural Sciences in China 5 (10): 751-757.

Naiola, B. P. (2000). Potensial Air pada Turgor Loss Point Tumbuhan Hutan Gambut dalam Kondisi Stres Genangan Dikawasan Sungai Sebangau, Kalimantan Tengah. Berita Biologi 5(3): 341-348.

Rifa'i, H., S. Ashari, dan Damanhuri. (2015). Keragaman 36 Aksesi Sorgum (Sorghum bicolor L.). Jurnal Produksi Tanaman 3(4): 330337

Salisbury, F.B. and C.W. Ross. (1992). Plant Physiology. 4rd Ed. California: Wadsworth Publishing Company.

Solikin. 2013. Pertumbuhan Vegetatif dan Generatif Tanaman Stachytarpheta jamaicensis (L) Vahl. Seminar Nasional Biologi X. FKIP, UNS Surakarta.

Subekti, N. A., Syafruddin, R. Efendi, dan S. Sunarti. 2011. Morfologi Tanaman dan Fase Pertumbuhan Jagung. Pusat Penelitian dan Pengembangan Tanaman Pangan. 1-11.

Tabri, F., dan Zubachtirodin. 2016. Budi Daya Tanaman Sorgum. Sorgum: Teknik Produksi dan Pengembangan. Balai Penelitian Tanaman Serealia 1:13. 